\title{
Lignolytic Enzyme Activity of Isolated Bacteria from Termite (Coptotermes sp.) and Milkfish (Chanos chanos Forsskal, 1775) Guts
}

\author{
Emi Latifah $^{1}$, Putri Dwi Mulyani ${ }^{1}$, Yekti Asih Purwestri ${ }^{1,2 *}$ \\ ${ }^{1}$ Biochemistry Laboratory, Faculty of Biology, Universitas Gadjah Mada, Indonesia \\ ${ }^{2}$ Research Center for Biotechnology, Universitas Gadjah Mada, Indonesia \\ *Corresponding Author: yekti@ugm.ac.id
}

Submitted: 2019-05-21. Revised: 2020-02-12. Accepted: 2021-02-23

\begin{abstract}
Bacteria BSR 2, Pseudomonas alcaligenes (BSR 3), Brevibacillus parabrevis (BSR 8), Brevibacillus sp. (BSR 9), isolated from termite gut and Bacillus licheniformis (BSA B1) isolated from milkfish gut have been known to possess cellulolytic activity. However, their lignolytic ability has not been known. This study aimed to determine the lignolytic ability of bacteria isolated from termit (Coptotermes sp.) and milkfish (Chanos chanos Forsskal, 1775) guts and their enzymes characterization. The qualitative test was done through the spot test method, while quantitative assay was performed spectrophotometrically at $335 \mathrm{~nm}$ to calculate vanillin concentration. The isolates were grown in Lignin Mineral Medium, then the optical density $\left(\mathrm{OD}_{620}\right)$ were measured every 24 hours for 5 days using spectrophotometer to determine their growth profile and the best isolation time of the lignolytic enzyme. Based on results, the best lignolytic enzyme isolation time for strains Bacillus licheniformis (BSA B1) and BSR 2 were 5 days, yielding lignolytic enzyme activity of $0.961 \pm 0.168 \mathrm{U} / \mathrm{mg}$ and $2.176 \pm 0.088 \mathrm{U} / \mathrm{mg}$ respectively, while strains Pseudomonas alcaligenes (BSR 3), Brevibacillus parabrevis (BSR 8), and Brevibacillus sp. (BSR 9) were 4 days, yielding of $1.206 \pm 0.045 \mathrm{U} / \mathrm{mg}, 1.162 \pm 0.191 \mathrm{U} / \mathrm{mg}$, and $0.896 \pm$ $0.108 \mathrm{U} / \mathrm{mg}$, respectively. The strain BSR 2 showed the highest lignolytic activity compared to other strains. The optimum temperature for lignolytic enzyme activity of BSR 2 was $30{ }^{\circ} \mathrm{C}$ and the optimum pH was 7 . The lignolytic enzyme activity showed that these bacterial isolates can be a chance to be used as new alternative lignolytic enzyme source in commercial bioconversion process.
\end{abstract}

Key words: lignolytic bacteria; lignolytic enzyme; milkfish gut; termite gut

How to Cite: Latifah, E., Mulyani, P. D., \& Purwestri, Y. A. (2021). Lignolytic Enzyme Activity of Isolated Bacteria from Termite (Coptotermes sp.) and Milkfish (Chanos chanos Forsskal, 1775) Guts. Biosaintifika: Journal of Biology \& Biology Education, 13(1), 7076.

DOI: http://dx.doi.org/10.15294/biosaintifika.v13i1.19333

\section{INTRODUCTION}

Lignin is a type of lignocellulose, which is the most abundant source of organic matter in the world (Dias et al., 2010; Plácido and Capareda, 2015). Lignin is one of the most complex bio-polymer and difficult to be degraded. In nature, its amount increases as results of massive lignocellulose based industries which produce lignocellulosic waste, including paper and plantation industry. There is a need to break lignin into simple compounds that are more useful and valuable. The compounds produced from lignin degradation have been known to possess potential application in various industries as alternative source of energy (Sahadevan et al., 2016). Lignin degradation can only be catalyzed by oxidative and unspecific extracellular lignolytic enzyme and depending on the depolymerized lignin structure. Peroxidases and laccases are two main group of enzymes that involved in lignin degradation (Falade et al., 2017).

Lignolytic enzyme production is generally carried out using microorganisms, especially fungi. In addition, some bacteria are known to have the potential to produce lignolytic enzyme. Enzymes produced by bacteria are expected to be superior compared to enzymes produced by fungus according to their thermostability, large-ranging $\mathrm{pH}$ tolerance, and fast growth rate (Bandounas et al., 2011; Falade et al., 2017; Lai et al., 2017). To the contrary, fungal genome has less agility to undergo similar adjustments, causing difficulties in the optimization process to yield fungal enzyme. This condition leads to the inability of fungi to be commersialized as biocatalytic agent in lignin degradation process (Falade et al., 2017). Unfortunately, lignolytic bacteria has not been explored much. Thus, many lignolytic bacterial enzymes are expected to be discovered.

Termite (Coptotermes sp.) is one of plant litterfeeding insects, while milkfish (Chanos chanos Forsskal, 1775) consumes detritus. Both plant litter and detritus are lignocellulosic material. Janatunaim et al. (2015a) have reported the cellulolytic ability of Bacillus licheniformis (BSA B1) isolated from milkfish gut. In the other side, four different bacteria originated from termit gut have also been reported to possess cellulolytic ability (Janatunaim et al., 2015b). Mulyani et al. (2018) identified them as 
Pseudomonas alcaligenes (BSR 3), Brevibacillus parabrevis (BSR 8), and Brevibacillus sp. (BSR 9), while BSR 2 is still unidentified. However, the lignolytic ability of the five mentioned bacteria has not been known.

Most of microorganism that is able to decompose polysaccharide in wood is unable to penetrate the lignificated tissue, unless the microorganism has lignolytic ability. According to Perez et al. (2002) in Marbun et al. (2016), it is because lignin has highly strong complex bonds and physically take a role as a resistor in cell wall destruction process. Therefore, the cellulolytic ability of isolated bacteria from termite and milkfish guts is thought to work along with their lignolytic ability. Hence, this study aimed to prove lignolytic ability of isolated bacteria from termite and milkfish gut and their enzymes characterization as well as their chance to be used as alternative agent in commercial bioconversion process.

\section{METHODS}

\section{Rejuvenation of the Bacterial Isolates}

Bacteria BSR 2, Pseudomonas alcaligenes (BSR 3), Brevibacillus parabrevis (BSR 8), Brevibacillus sp. (BSR 9), isolated from termite gut and Bacillus licheniformis (BSA B1) isolated from milkfish gut were rejuvenated on Nutrient Agar (NA) slant, then incubated at $37^{\circ} \mathrm{C}$ until the bacteria grew. The composition of NA per liter of distilled water were $5.0 \mathrm{~g}$ pepton, $3.0 \mathrm{~g}$ beef extract, $5.0 \mathrm{~g} \mathrm{NaCl}$, and $20 \mathrm{~g}$ bactoagar.

\section{Detection of lignolytic bacterial isolates}

Detection was done by performing qualitative testing using spot test method. Spot test was ran by dripping $1 \%$ pyrogallol solution which has been mixed with $0.4 \% \mathrm{H}_{2} \mathrm{O}_{2}$ (composition 1: 1) on the edge of the test culture (which was still actively growing). Culture was observed at 24, 48 , and 72 hours after the dripping. The brownish yellow color showed the presence of peroxidase enzyme activity. The spot test was continued to detect laccase enzyme activity using reagent $0.1 \mathrm{M}$ 1-naphthol dissolved in 96\% ethanol. The method and time of observation were carried out similar to the peroxidase test above. Positive results were indicated by the appearance of purplish red color (Agustini et al., 2011).

\section{Growing bacterial isolate in Lignin Mineral Medium (LMM)}

The selective growth media used was the Lignin Mineral Medium (LMM) following Prakoso et al. (2014), with carbon source replaced by alkali lignin. LMM was made by the composition (per liter distilled water) of $1.55 \quad \mathrm{~g} \quad \mathrm{~K}_{2} \mathrm{HPO}_{4}, \quad 0.85 \quad \mathrm{~g}$ $\mathrm{NaH}_{2} \mathrm{PO}_{4} \cdot 2 \mathrm{H}_{2} \mathrm{O}, 2.0 \mathrm{~g}\left(\mathrm{NH}_{4}\right)_{2} \mathrm{SO}_{4}, 0.1 \mathrm{~g} \mathrm{MgCl}_{2} \cdot 6 \mathrm{H}_{2} \mathrm{O}$, $10 \mathrm{mg}$ EDTA, $2.0 \mathrm{mg} \mathrm{ZnSO}_{4} \cdot 7 \mathrm{H}_{2} \mathrm{O}, 1.0 \mathrm{mg}$ $\mathrm{CaCl}_{2} .2 \mathrm{H}_{2} \mathrm{O}$, 5.0 mg $\mathrm{FeSO}_{4} .7 \mathrm{H}_{2} \mathrm{O}, 0.2 \mathrm{mg}$ $\mathrm{Na}_{2} \mathrm{MoO}_{4} .2 \mathrm{H}_{2} \mathrm{O}, 0.2 \mathrm{mg} \mathrm{CuSO}_{4} .5 \mathrm{H}_{2} \mathrm{O}, 0.4 \mathrm{mg}$ $\mathrm{CoCl}_{2} \cdot 6 \mathrm{H}_{2} \mathrm{O}, 1.0 \mathrm{mg} \mathrm{MnSO}_{4} \cdot 2 \mathrm{H}_{2} \mathrm{O}, 0.5 \mathrm{mg} \mathrm{CuSO}$, $0.1 \mathrm{~g}$ Yeast Extract, and $1.0 \mathrm{~g}$ Alkali Lignin (Indulin AT).

Isolate was acclimatized in LMM agar, grown in liquid LMM, and incubated in shaker incubator at $30^{\circ} \mathrm{C}$ and rotation of $125 \mathrm{rpm}$. The bacterial growth curve was made by measuring the optical density (OD) of bacteria every 24 hours for 5 days at wavelength of $620 \mathrm{~nm}$ using a UV-Vis spectrophotometer.

\section{Crude enzyme isolation}

The crude enzyme was obtained by centrifuging bacterial culture every 24 hours for 5 days at a speed of $5000 \mathrm{rpm}$ at $4^{\circ} \mathrm{C}$ for 15 minutes, then taking its supernatant (Tampoebolon et al., 2014)

\section{Total protein concentration}

The measurement of protein concentration was done using spectrophotometric method with direct absorbance at wavelength $280 \mathrm{~nm}$ using a standard curve BSA (Bovine Serum Albumin) and using sterile double-distilled water as the blank (Mulyani et al., 2018).

\section{Measurement of enzyme activity}

Measurements of enzyme activity were carried out by preparing a substrate source in the form of alkali lignin which was dissolved in phosphate buffer 50 $\mathrm{m} \mu \mathrm{pH} \mathrm{7,} \mathrm{generating} 1 \%$ concentration substrate solution. A total of $0.8 \mathrm{ml}$ substrate source then was added by $0.1 \mathrm{ml}$ of rough extract enzyme and $0.1 \mathrm{ml}$ of distilled water. The mixture was then incubated for $30 \mathrm{~min}$.

The process which formed vanillin, measured by adding $0.1 \mathrm{ml}$ of incubated mixture into $2.4 \mathrm{ml}$ of methanol and vortexed to homogenize and measured its absorbance at wavelength of $335 \mathrm{~nm}$. The results obtained were then compared to the standard curve of vanillin (Martani, et al., 2003: KEMENKES, 2013; Tampoebolon et al., 2014). The lignolytic enzyme activity was measured every 24 hours for 5 days to determine the optimum time for enzyme activity.

\section{Optimization of temperature and pH for bacterial lignolytic enzyme activity}

The determination of the optimum temperature was tested by measuring the lignolytic enzyme activity at temperature variations of $25,30,37,40$, 55 , and $70^{\circ} \mathrm{C}$ in the lignin substrate dissolved in a $\mathrm{pH}$ 7 buffer with 30 minutes incubation. Meanwhile the 
determination of optimum $\mathrm{pH}$ was carried out by dissolving enzyme source into dissolved lignin

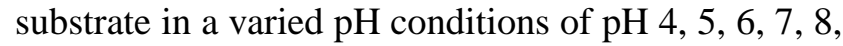
9 , and 10.

\section{Data analysis}

Quantitative data in the form of bacterial lignolytic activity, incubation time, optimum temperature and $\mathrm{pH}$ were analyzed statistically based on ANOVA and DMRT $(\mathrm{P} \leq 0.05)$ using SPSS v.20.0.

\section{RESULTS AND DISCUSSION}

\section{Detection of Lignolytic Ability of Bacterial Isolates from Termite and Milkfish Gut}

Detection of lignolytic ability of BSR 2 isolates, Pseudomonas alcaligenes (BSR 3) and Bacillus licheniformis (BSA B1) showed positive results for both laccase and peroxidase tests, meanwhile bacterial isolates Brevibacillus sp. (BSR 9) was only positive for the peroxidase test, and Brevibacillus parabrevis (BSR 8) bacterial isolates showed negative results for both enzymes. This results were indicated by the absence of a colored zone around the colony after dropping the reagent (Figure 1).
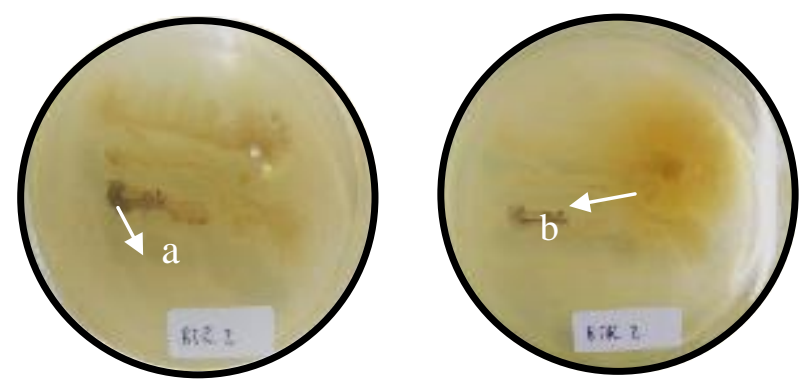

BSR 2
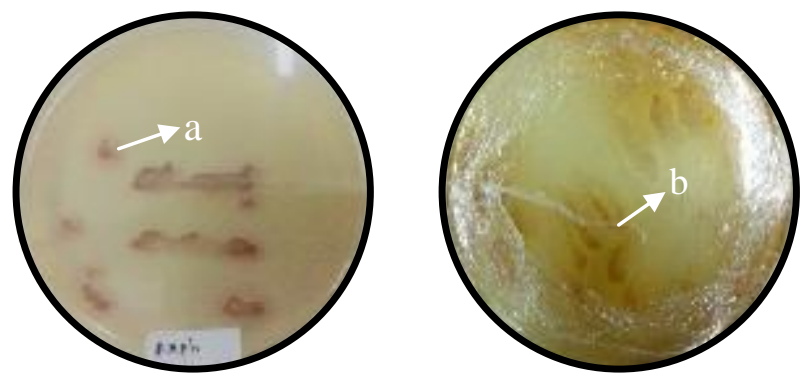

Pseudomonas alcaligenes (BSR 3)
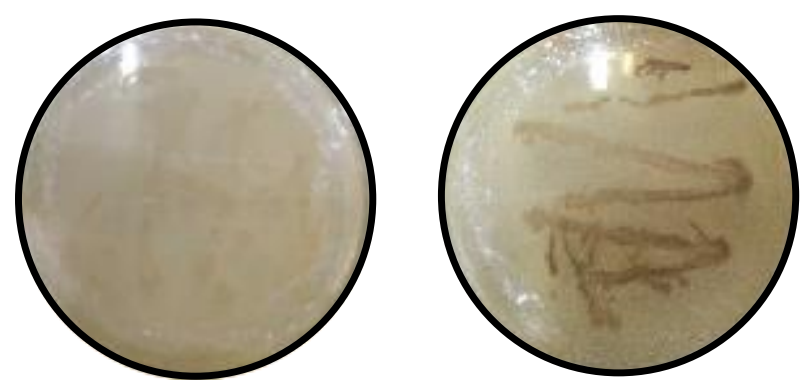

Brevibacillus parabrevis (BSR 8)
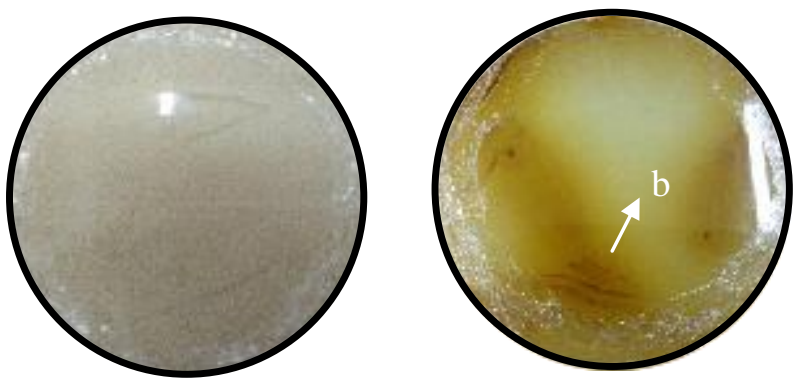

Brevibacillus sp. (BSR 9)
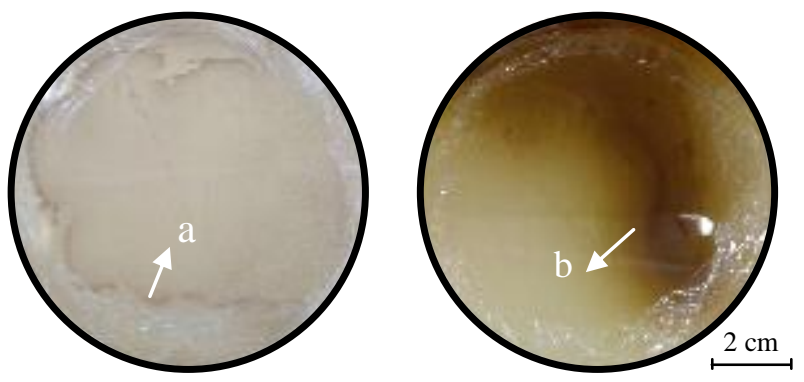

Bacillus licheniformis (BSA B1)

Figure 1. Qualitative test of laccases (a) and peroxidases (b) activity.

Positive results of laccases and peroxidases were indicated by formation of colored zone around the bacterial colony. Laccases oxidized 1-naphthol, a polycyclic aromatic hydrocarbon compound, into a new polymeric compound. During 1-naphthol oxidizing process, a purplish product was formed, resulting a purple-red to deep purple zone around the colony (Khammuang and Sharntima, 2009). Pyrogallol is one of phenolic compounds, which in general, oxidized phenol will form colored compounds. Peroxidases oxidized pyrogallol using $\mathrm{H}_{2} \mathrm{O}_{2}$ as an electron acceptor, producing a colored product compound and water (Bach et al., 2013). Although, not all of the isolates showed positive results, but they could grow on selective medium LMM agar using lignin as the only carbon source, thus the five isolates were used in quantitative assay. 


\section{Bacterial Isolates Growth in Lignin Mineral Medium}

The growth curve showed that bacterial isolate of Pseudomonas alcaligenes (BSR 3) had the highest growth and significant difference $(\mathrm{P} \leq 0.05)$ compared to the other four isolates since day 1 to day 5 of incubation (Figure 2). On day 1, the growth of Brevibacillus parabrevis (BSR 8) isolate did not show a significant difference $(\mathrm{P}>0.05)$ compared to Bacillus licheniformis (BSA B1), BSR 2 and Brevibacillus sp. (BSR 9) isolates. However, the BSR 2 and Brevibacillus sp. (BSR 9) isolates compared to Bacillus licheniformis (BSA B1) isolate showed significantly different growth $(\mathrm{P} \leq 0.05)$. Only on day 4 to 5, BSR 2 isolates experienced growth that was significantly different $(\mathrm{P} \leq 0.05)$ compared to the other three isolates. On the last day of incubation, Bacillus licheniformis (BSA B1), Brevibacillus parabrevis (BSR 8), and Brevibacillus sp. (BSR 9) showed $O D$ values that were not significantly different $(\mathrm{P}>0.05)$.

The optical density (OD) of bacterial isolates was measured to know their growth rate. As shown at Figure 2, there were differences of five isolates growth rate. According to Black (2012), growth rate differences were affected by physics and biochemistry factors. The decrease of bacterial growth could be caused by nutrient depletion or accumulation of waste products in the medium either their combinations (Allen and Waclaw, 2019). During lignin degradation process, certain intermediate compounds are produced. These compounds are known to be recalcitrant and toxic to organism (Kumar and Chandra, 2020). It was possible that the compounds decrease the growth of bacteria itself (Martani et al., 2003).

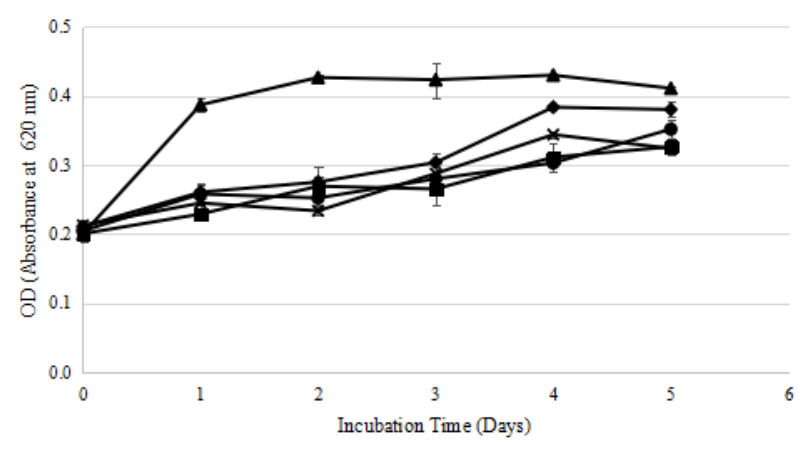

Figure 2. Growth of bacterial isolates from termite and milkfish gut. (») BSR 2, (ロ) Bacillus licheniformis BSA B1, ( $\mathbf{\Delta})$ Pseudomonas alcaligenes BSR 3, (×) Brevibacillus parabrevis BSR 8, (•) Brevibacillus sp. BSR 9

The measurement of bacterial growth spectrophotometrically, in general, did not show the decreasing OD value, because spectrophotometer read culture turbidity which are not only affected by living bacterial cells but also the entire cells in the culture, included the dead cells (Black, 2012). However, in this study there were several data that showed a decrease in the value of OD. This case occurred because of the inhomogeneous shaking before sampling that only a few cells were inserted.

\section{Production Period of Lignolytic Enzyme}

Based on the results of the study, it was found that the optimum incubation time to obtain the highest lignolytic enzyme activity of isolates Pseudomonas alcaligenes (BSR 3), Brevibacillus parabrevis (BSR 8), and Brevibacillus sp. (BSR 9) was 4 days, with the value of lignolytic enzyme specific activity were $1.206 \pm 0.045 \mathrm{U} / \mathrm{mg}, 1.162 \pm 0.191 \mathrm{U} / \mathrm{mg}$, and $0.896 \pm 0.108 \mathrm{U} / \mathrm{mg}$, respectively. Meanwhile, isolate BSR 2 and Bacillus licheniformis (BSA B1) did not show their decrease in specific enzyme activity up to the fifth day with activity value of $2.176 \pm 0.088 \mathrm{U} / \mathrm{mg}$ and $0.961 \pm 0.168 \mathrm{U} / \mathrm{mg}$ (Figure $3)$. Based on the data, BSR 2 was the isolate that had the highest lignolytic ability compared to other isolates so that it was chosen as the isolate to be used in further testing.

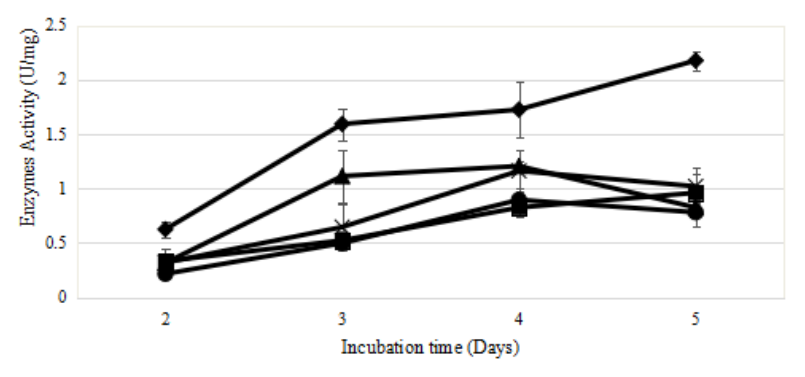

Figure 3. Measurement of lignolytic enzymes activity of bacterial isolates from termite and milkfish guts. ( ) BSR 2, (ロ) Bacillus licheniformis BSA B1, $(\boldsymbol{\Delta})$ Pseudomonas alcaligenes BSR 3, ( $\mathbf{x})$ Brevibacillus parabrevis BSR $8,(\bullet)$ Brevibacillus $\mathrm{sp.}$ BSR 9

In this study, lignolytic enzyme activity was calculated based on the concentration of vanillin formed as one of the lignin depolymerization products. Brevibacillus parabrevis (BSR 8) showed negative results in the qualitative test, but the quantitative test gave the third highest activity results after BSR 2 and Pseudomonas alcaligenes (BSR 3). This is possible because of the different types of lignolytic enzymes produced. Laccase and peroxidase are the two most common groups of enzymes, but there are also other groups of enzymes, such as the enzyme superoxide dismutase, $\beta$-etherase, and dioxygenase (Gonzalo et al., 2016). 
Isolate BSR 2 showed the highest lignolytic enzyme activity since its first 48 hours incubation, compared to other isolates and continued to increase significantly until the end of the incubation period in the 5th day. Therefore, BSR 2 isolate was chosen as the isolate to be used in the test of the effect of temperature and $\mathrm{pH}$.

\section{Environment effect against isolate BSR 2 lignolytic enzyme activity}

In this study, the effect of temperature and $\mathrm{pH}$ factors on the activity of lignolytic enzyme of BSR 2 isolate was observed. Based on Figure 4, lignolytic enzyme activity reached its optimum point at $30^{\circ} \mathrm{C}$ with a specific activity value of $2.176 \pm 0.088 \mathrm{U} / \mathrm{mg}$. At a temperature of $25^{\circ} \mathrm{C}, 37^{\circ} \mathrm{C}, 40^{\circ} \mathrm{C}, 55^{\circ} \mathrm{C}$, and $70^{\circ} \mathrm{C}$, lignolytic enzyme activities of isolate BSR 2 were $0.732 \pm 0.067 \mathrm{U} / \mathrm{mg}, 1.655 \pm 0.116 \mathrm{U} / \mathrm{mg}$, $1.529 \pm 0.225 \mathrm{U} / \mathrm{mg}, 0.283 \pm 0.103 \mathrm{U} / \mathrm{mg}$, and $0.053 \pm 0.019 \mathrm{U} / \mathrm{mg}$, respectively.

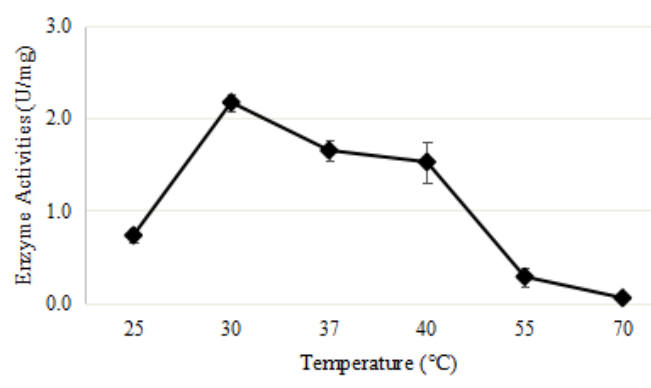

Figure 4. Lignolytic enzyme activity of isolates BSR 2 in various temperature variations.

The increase in lignolytic enzyme activity of isolate BSR 2 at an incubation temperature of $30^{\circ} \mathrm{C}$ from a temperature of $25^{\circ} \mathrm{C}$ showed a significantly different value $(\mathrm{P} \leq 0.05)$. The enzyme activity continued to show a significant decrease $(\mathrm{P} \leq 0.05)$ at the incubation temperature of $37^{\circ} \mathrm{C}$ to $70^{\circ} \mathrm{C}$, except at $40^{\circ} \mathrm{C}$ which the decrease was not significant $(\mathrm{P}>$ 0.05) compared to the enzyme activity at the temperature of $37^{\circ} \mathrm{C}$. This can occur considering the temperature difference is only 3 degrees that it does not significantly affect enzyme activity.

Rajeswari and Bhuvaneswari (2016) reported that laccase produced by strains of Pseudomonas putida and Bacillus sp., optimum at an incubation temperature of $40-50^{\circ} \mathrm{C}$. While Singh, et al. (2014) reported that Bacillus licheniformis produced laccases at optimal temperature of $37^{\circ} \mathrm{C}$ on neutral $\mathrm{pH}$. These are different from the results of this study where the optimum temperature obtained was $30^{\circ} \mathrm{C}$. This difference can occur because of the differences in bacterial strains as a source of enzymes which resulted in different physiological characteristics.
El Salam and Bahobail (2016) conducted a lignolytic activity test on the thermophilic bacteria isolated from Saudi Arabia and showed the optimum lignolytic activity temperature at $55^{\circ} \mathrm{C}$. This further reinforces the evidence that differences in the natural environment of the bacteria also influence the difference in the optimum temperature for lignolytic enzyme activity.

Based on Figure 5, lignolytic enzyme activity reached its optimum point at $\mathrm{pH} 7$ with a specific activity value of $2.176 \pm 0.088 \mathrm{U} / \mathrm{mg}$. Lignolytic enzyme activity at $\mathrm{pH} 4$ showed values of $0.170 \pm$ $0.036 \mathrm{U} / \mathrm{mg}$ and at $\mathrm{pH} 10$ showed an activity value of $0.987 \pm 0.230 \mathrm{U} / \mathrm{mg}$.

In the $\mathrm{pH}$ effect test, the enzyme activity increased significantly $(\mathrm{P} \leq 0.05)$ as $\mathrm{pH}$ increased to reach its optimum number on neutral $\mathrm{pH}$. Enzyme activity again, decreased along with the decrease of $\mathrm{pH}$ with significant different value $(\mathrm{P} \leq 0.05)$. After the decrease of $\mathrm{pH}$ with significant different value $(\mathrm{P} \leq 0.05)$ on $\mathrm{pH} 8$, it was shown that lignolytic enzyme activity experience significant increase on $\mathrm{pH}$ 9. Meanwhile, on $\mathrm{pH} 7$ and $\mathrm{pH} 9$, data of insignificant lignolytic enzyme activity $(\mathrm{P}>0.05)$ were collected. This was possible due to the less homogeneous culture that was shaken before sampling to isolate crude enzymes so that the bacteria taken were insufficient and resulted in a low activity value. The data above present that lignolytic enzyme isolated from BSR 2 is optimum on neutral condition with narrow range and relatively work better on alkali than acidic $\mathrm{pH}$ range.

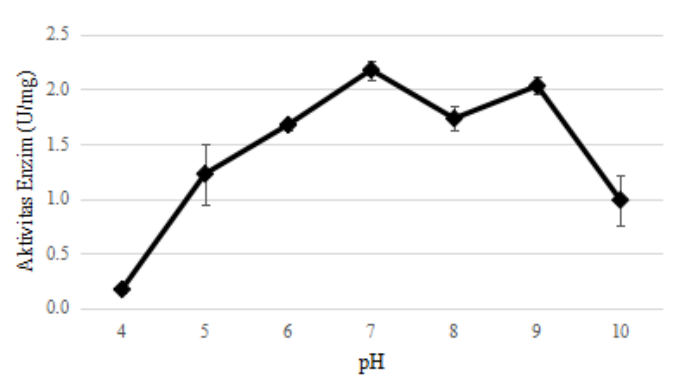

Figure 5. Lignolytic enzyme activity isolates BSR 2 in various $\mathrm{pH}$ variations.

A study by Bach et al. (2012) showed a relevance results, which is lignolytic enzyme activity from both laccase and peroxidase groups that showed higher results in neutral to alkali conditions compared to acidic $\mathrm{pH}$ conditions. Meanwhile El Salam and El Hanafy (2009) reported that lignin degradation activity performed by bacteria displayed optimum results on $\mathrm{pH}$ 6. This difference is possible due to the difference of the bacterial natural environment. According to Black (2012), the optimum pH of an 
enzyme is generally related to the natural environment of the enzyme-producing organism.

This study gave us information about new several lignolytic bacteria from termite and milkfish guts. These bacteria produce extracellular enzyme that degrade lignin, thus termite and milkfish could digest organic material containing lignocellulosic compound. It reconfirmed that termite and milkfish ability to digest lignocellulosic material was not because of its guts enzyme but because their symbiosis with lignolytic bacteria in their guts. This study also gave information about the characterization of the enzyme produced by each bacterial isolate and which isolate had the highest enzyme activity. Based on results, the four isolates; BSR 2, Pseudomonas alcaligenes (BSR 3), Brevibacillus parabrevis (BSR 8), Brevibacillus sp. (BSR 9), and Bacillus licheniformis (BSA B1) were able to degrade substrates used in the research as the result of their lignolytic enzyme production. BSR 2 was the isolate with the highest lignolytic enzyme activity in the range of normal temperature and $\mathrm{pH}$, showed its high potency as an alternative agent of commercial bio-convertion process of lignin, the most abundant and hard degrade biopolymer.

\section{CONCLUSION}

Bacterial isolate of Bacillus licheniformis (BSA B1), BSR 2, Pseudomonas alcaligenes (BSR 3), Brevibacillus parabrevis (BSR 8), and Brevibacillus sp. (BSR 9) from termite (Coptotermes sp.) and milkfish (Chanos chanos Forsskal, 1775) digestive tract can produce lignolytic enzyme. Among the bacterial isolates, BSR 2 showed the highest lignolytic enzyme activity with the value of $2.176 \pm$ $0.088 \mathrm{U} / \mathrm{mg}$ on the fifth day of incubation time. The lignolytic enzyme activity was optimum at the temperature of $30^{\circ} \mathrm{C}$, and on the $\mathrm{pH}$ of 7 . This showed BSR 2 potencial as a new alternative agent of commercial bioconvertion process of lignin.

\section{ACKNOWLEDGEMENT}

The authors thank to Prof. Dietmar Haltrich, BOKU University for the valuable discussion during this research.

\section{REFERENCES}

Allen, R. J., \& Waclaw, B. (2019). Bacterial growth: A statistical physicist's guide. Reports on Progress in Physics, 82(1), 016601.

Agustini, L., Irianto, R. S. B., Turjaman, M., \& Santoso, E. (2011). Characterization of lignocellulolytic microbes collected from three types of national park ecosystems. Jurnal Pendidikan Hutan dan Konservasi Alam, 8(2), 197-210.

Bach, C. E., Warnock, D. D., van Horn, D. J., Weintraub, M. N., Sinsabaugh, R. L., Allison, S. D., \& German, D. P. (2013). Measuring phenol oxidase and peroxidase activites with pyrogallol, L-DOPA, and ABTS: effect of assay conditions and soil type. Soil Biology and Biochemistry, 67, 183-191.

Bandounas, L., Wierckx, N. J. P., de Winde, J. E., \& Ruijssenaars, H. J. (2011). Isolation and characterization of novel bacterial strains exhibiting lignolytic potential. $B M C$ Biotechnology, 11, 94.

Black, J. G. (2012). Microbiology: Principles and Explorations, $8^{\text {th }}$ Edition. USA: John Wiley \& Sons.

Dias, A. A., Freitas, G. S., Marques, G. S. M., Sampaio, A., Fraga, I. S., Rodrigues, M. A. M., Bezerra, R. M. F. (2010). Enzymatic saccharification of biologically pre-treated wheat straw with white-rot fungi. Bioresource Technology, 101, 6045-6050.

El Salam, H. E. A., \& Bahobail, H. S. (2014). Lignin biodegradation by thermophilic bacterial isolates from Saudi Arabia. Research Journal of Pharmaeutical, Biological and Chemical Science, 7(1), 1413-1424.

El Salam, H. E. A., \& El Hanafy, A. A. (2009). Lignin biodegradation with ligninolytic bacterial strain and comparison of Bacillus subtilis and Bacillus sp. isolated from egyptian soil. AmericanEurasian Journal of Agricultural \& Environmental Sciences, 5(1), 39-44.

Falade, A. O., Eyisi, O. A. L., Mabinya, L. V., Nwodo, U. U., \& Okoh, A. I. (2017). Peroxidase production and ligninolytic potentials of fresh water bacteria Raoultella ornithinolytica and Ensifer adhaerens. Biotechnology Reports, 16(2017), 12-17.

Gonzalo, G., Colpa, D. I., Habib, M. H. M., \& Fraaije, M. W. (2016). Bacterial enzymes involved in lignin degradation. Journal of Biotechnology, 236, 110-119.

Janatunaim, R. Z., Hamid, R. M., Christy, G. P., Purwestri, Y. A., \& Tunjung, W. A. S. (2015a). Identification of BSA B1 bacteria and its potency of purified cellulase to hydrolize Chlorella zofingiensis. Indonesian Journal of Biotechnology, 20(1), 77-87.

Janatunaim, R. Z., Wijaya, C., Ridha, A., Ramadhani, E., Priyambada, F., \& Purwestri Y. A. (2015b). Characterization of cellulase in the cellulolytic bacteria of termites (order: Isoptera) as composting accelerator agensia. In L. O. M. Y. 
Haya (Ed.), Proceedings of the hokkaido indonesian student association scientific meeting (HISAS): Vol. $12 I$ (pp. 8-12). Siaga Printing.

Khammuang, S., \& Sharntima, R. (2009). Mediatorassisted rhodamine B decolorization by Trametes versicolor laccase. Pakistan Journal of Biological Sciences, 12(8), 616-623.

[KEMENKES] Kementerian Kesehatan RI Direktorat Jenderal Bina Kefarmasian dan Alat Kesehatan. (2013). Farmakope Indonesia Edisi V. Jakarta.

Kumar, A., \& Chandra, R. (2020). Ligninolytic enzymes and its mechanisms for degradation of lignocellulosic waste in environment. Heliyon, 6(2020) e03170.

Lai, C. M. T., Chua, H. B., Danquah, M. K., \& Saptoro, A. (2017). Isolation of thermophilic lignin degrading bacteria from oil-palm empty fruit brunch (EFB) compost. In A. Saptoro, W. S. Khur, L. S. Wei, W. P. Q. Ng, M. Anwar, C. Yeo, \& K. E. Huey (Eds.), IOP Conference Series: Materials Science and Engineering: Vol. 206. $29^{\text {th }}$ Symposium of Malaysian Chemical Engineers (SOMChe) 2016. IOP Publishing.

Marbun, J. Y. F., Sutama, I. N. S., Mudita, I. M., \& Wijana, I. W. (2016). Kemampuan degradasi dari isolat bakteri lignolitik asal cacing tanah (Lumbricus rubellus) pada substrat gulma tanaman pangan. Peternakan Tropika, 4(3), 700-713.

Martani, E., Haedar, N., \& Margino, S. (2003). Isolation and characterization of lignin degrading bacteria from several natural substrates. Gama Sains V(2), 97-107.

Mulyani, P. D., Hamid, R. M., Janatunaim, R. Z., \& Purwestri, Y. A. (2018). Amylolytic ability of bacteria isolated from termite (Coptotermes sp.) gut. Indonesian Journal of Biotechnoogy, 23(1), 14-20.

Plácido, J., \& Capareda, S. (2015). Ligninolytic enzymes: a biotechnological alternative for bioethanol production. Bioresources and Bioprocessing, 20152,23.

Prakoso, H. T., Widiastuti, H., Suharyanto, \& Siswanto. (2014). Eksplorasi dan karakterisasi bakteri aerob ligninolitik serta aplikasinya untuk pengomposan tandan kosong kelapa sawit. Menara Perkebunan, 82(1), 15-24.

Rajeswari, M., \& Bhuvaneswari, V. (2016). Production of Extracelluler Laccase from the Newly Isolated Bacillus sp. PK4. African Journal of Biotechnology, 15(34), 1813-1826.

Sahadevan, L. D. M., Misra, C. S., \& Thankamani, V. (2016). Characterization of lignin-degrading enzymes (LDEs) from a dimorphic novel fungus and identification of products of enzymatic breakdown of lignin. Biotechnology, 6, 56 .

Singh, D., Narang, E., Chutani, P., Kumar, A., Sharma, K. K., Dhar, M. \& Virdi, J. S. (2014). Isolation, characterization, and production of bacterial laccase from Bacillus sp.. in R. Kharwar, R. Uppadhyay, N. Dubey, \& R. Raghuwanshi (Eds.), Microbial diversity and biotechnology in food security (pp. 439-450). Springer.

Tampoebolon, B. I. M., Bachruddin, Z., Yusiati, L. M., \& Margino, S. (2014). Isolation and lignocellulytic activities of fiber-digesting bacteria from digestive tract of termite (Cryptothermes sp.). Journal of Indonesian Tropical Animimal Agriculture, 39(4), 224-234. 